\title{
PENGARUH PENDIDIKAN KESEHATAN TERHADAP TINGKAT PENGETAHUAN REMAJA DALAM PENCEGAHAN PENYALAHGUNAAN NAFZA DI SMA KATOLIK ST. PETRUS KANISIUS PALANGKA RAYA
}

\author{
Putria Carolina $^{1}$, Yelstria Ulina Tarigan ${ }^{2}$ \\ 1,2Dosen Pengajar Program Studi Sarjana Keperawatan Sekolah Tinggi IImu Kesehatan Eka \\ Harap Palangka Raya \\ Email: putria ekaharap@yahoo.co.id
}

\begin{abstract}
ABSTRAK
Narkotika, psikotropika, dan zat adiktif (NAPZA) merupakan zat atau obat yang berasal dari tanaman atau bukan tanaman baik sintetis maupun semisintetis yang dapat menyebabkan penurunan atau perubahan kesadaran, hilangnya rasa, mengurangi sampai menghilangkan rasa nyeri, dan dapat menimbulkan ketergantungan, yang dibedakan ke dalam golongangolongan sebagaimana terlampir dalam Undang Undang RI Nomor 35 Tahun 2009. Data dari Badan Narkotika Nasional Provinsi Kalimantan Tengah tahun 2015, diketahui jumlah penyalahguna NAPZA yang direhabilitasi dengan usia 15-20 tahun sebanyak 46 orang (13,9\%) dari 330 orang (BNNP Kalimantan Tengah, 2015).

Tujuan penelitian ini adalah untuk mengetahui apakah ada pengaruh pemberian pendidikan kesehatan terhadap tingkat pengetahuan remaja dalam pencegahan penyalahgunaan NAPZA di SMA Katolik St. Petrus Kanisius Kota Palangka Raya.

Penelitian ini menggunakan jenis penelitian pra eksperimental dengan pendekatan one group pra post test dengan uji wilcoxon. Populasi dalam penelitian ini adalah siswa SMA Katolik St. Petrus Kanisius Palangka Raya yang berjumlah 47 orang, dengan menggunakan simple random sampling.

Melalui hasil analisis dalam penelitian ini didapatkan nilai $Z$ untuk pengetahuan yaitu $-5.514^{a}$ dengan $P$ Value Asymp.Sig. (2-tailed) pengetahuan 0.000 yang berarti lebih kecil dari $a=0.05$, sehingga disimpulkan $P$ Value $\leq 0,05$ maka Ha diterima. Artinya terdapat pengaruh pendidikan kesehatan terhadap tingkat pengetahuan remaja dalam pencegahan penyalahgunaan NAPZA di SMA Katolik St. Petrus Kanisius Kota Palangka Raya.

Saran bagi petugas kesehatan berdasarkan hasil penelitian ini kiranya dapat meningkatkan peran sebagai edukator dalam meningkatkan pengetahuan yang diharapkan dapat menjadi dasar terjadinya perubahan perilaku pada remaja agar tidak menggunakan obat-obatan terlarang yang berdampak buruk bagi kesehatan.
\end{abstract}

Kata Kunci: Pengetahuan, Remaja, NAPZA.

\begin{abstract}
Narcotics, psychotropic substances and addictive substances (NAPZA) are substances or drugs derived from plants or not synthetic or semisynthetic plants that can cause a decrease or change in consciousness, loss of taste, reduce pain relief, and can cause dependence, which is differentiated into in groups as attached in the Republic of Indonesia Law Number 35 of 2009. Data from the National Narcotics Agency in Central Kalimantan in 2015, it was known that the number of rehabilitated drug users with 15-20 years of age was 46 people (13.9\%) out of 330 people (BNNP Central Kalimantan, 2015).

The purpose of this study was to find out whether there was an effect of the provision of health education on the level of knowledge of adolescents in preventing drug abuse in Catholic High School St. Petrus Kanisius, Palangka Raya City.
\end{abstract}


Pengaruh Pendidikan Kesehatan Terhadap Tingkat Pengetahuan Remaja Dalam

Pencegahan Penyalahgunaan Nafza Di SMA Katolik St. Petrus Kanisius Palangka Raya

This study uses a type of pre-experimental research with a one group pre post test approach with Wilcoxon test. The population in this study were Catholic High School St. Petrus Kanisius, Palangka Raya City totaling 47 students, using simple random sampling.

Through the results of the analysis in this study obtained the value of $Z$ for knowledge that is $-5,514 a$ with $P$ Value Asymp.Sig. (2-tailed) knowledge of 0,000 which means it is smaller than $\mathrm{a}=0.05$, so it is concluded $\mathrm{P}$ Value $\leq 0.05$, then $\mathrm{Ha}$ is accepted. This means that there is an influence of health education on the level of knowledge of adolescents in preventing drug abuse in Catholic High School St. Petrus Kanisius, Palangka Raya City.

Suggestions for health workers based on the results of this study should be able to increase the role of educators in increasing knowledge which is expected to be the basis for behavior changes in adolescents so that they do not use illegal drugs that have a negative impact on health.

Keywords: Knowledge, Students, Drug.

\section{PENDAHULUAN}

Narkotika, psikotropika, dan zat adiktif (NAPZA) merupakan zat atau obat yang berasal dari tanaman atau bukan tanaman baik sintetis maupun semisintetis yang dapat menyebabkan penurunan atau perubahan kesadaran, hilangnya rasa, mengurangi sampai menghilangkan rasa nyeri, dan dapat menimbulkan ketergantungan, yang dibedakan ke dalam golongan-golongan sebagaimana terlampir dalam Undang Undang $\mathrm{RI}$ Nomor 35 Tahun 2009. Masa remaja adalah masa transisi dari masa kanak-kanak menuju dewasa, sehingga dalam proses pencarian jati diri cenderung sering salah dalam bergaul sehingga banyak melakukan hal yang menyimpang dari norma-norma yang berlaku di masyarakat seperti penyalahgunaan NAPZA ${ }^{1}$. Sebuah hasil penelitian mengatakan pengetahuan merupakan aspek kognitif yang diidentifikasi berperan penting dalam penyalahgunaan, berupa rendahnya pengetahuan tentang NAPZA².
Berdasarkan data World Drug Report jumlah pengguna NAPZA di tingkat global dengan populasi usia antara 15-64 tahun mencapai 246 juta orang atau setara dengan $5.2 \%$ populasi dunia ${ }^{3}$. Jumlah penyalahguna NAPZA diperkirakan ada sebanyak 3,8 juta sampai 4,1 juta orang yang pernah memakai NAPZA dalam setahun terakhir (current users) pada kelompok usia 10-59 tahun pada tahun 2014 di Indonesia. Sedangkan jumlah penyalahguna NAPZA di Kalimantan Tengah tahun 2014 berjumlah 35.811 orang (1.95\%) dari populasi usia 10-59 tahun berjumlah $1.835 .300^{4}$. Data dari Badan Narkotika Nasional Provinsi Kalimantan Tengah tahun 2015, diketahui jumlah penyalahguna NAPZA yang direhabilitasi dengan usia 15-20 tahun sebanyak 46 orang $(13,9 \%)$ dari 330 orang $^{5}$.

Berkembangya jumlah pecandu pada kalangan remaja disebabkan karena adanya minat, rasa ingin tahu (curiosity), lemahnya rasa Ketuhanan, dan ketidak 
stabilan emosi. Sedangkan yang berasal dari luar diri sendiri adalah gangguan psiko-sosial keluarga, lemahnya hukum terhadap pengedar dan pengguna NAPZA, lemahnya sistem sekolah termasuk bimbingan dan konseling (BK), serta yang terpenting lemahnya pendidikan agama para siswa sekolah. Sebagai akibatnya, lama-kelamaan generasi muda itu bergantung kepada zat-zat tersebut dan sukar untuk melepaskan diri karena mereka telah kecanduan. Pemakaian yang berulang-ulang akan bergantung secara fisik dan psikis terhadap NAPZA, dan tidak bisa dihentikan ${ }^{6}$. Informasi tentang NAPZA dan dampak penyalahgunaannya dapat diberikan untuk menambah pengetahuan remaja, dampak positif bila seseorang atau kelompok diberikan pendidikan tentang bahaya NAPZA, maka akan mempengaruhi sikap mereka untuk berperilaku sesuai nilai-nilai kesehatan. Sedangkan dampak negatif bila kurang atau tidak mendapatkan pendidikan tentang bahaya NAPZA, maka dikhawatirkan akan terjadi perubahan sikap yang dapat membahayakan diri sendiri maupun lingkungan.

Perawat memiliki peran yang penting untuk membantu menghadapi permasalahan NAPZA di sekolah, yaitu dengan cara preventif dan promotif. Peran perawat dari segi preventif sendiri adalah berupa pemberian pendidikan kesehatan mengenai NAPZA bagi remaja di masyarakat untuk memperingati dan mengurangi penyalahgunaan NAPZA sedini mungkin. Sedangkan peran perawat dari segi promotif dengan meningkatkan dukungan kepada masyarakat dalam melawan penyalahgunaan NAPZA terutama dikalangan muda. Selain itu perawat juga dapat bekerja sama dengan pihak keluarga dengan menganjurkan orang tua menciptakan kehidupan rumah tangga yang lebih harmonis dan beragama serta selalu memperhatikan keadaan anakanaknya termasuk pergaulannya.

\section{METODE PENELITIAN}

Desain dalam penelitian ini adalah dengan rancangan Pra-eksperimental dengan pendekatan one Group pra-post test design yang mengungkapkan hubungan sebab akibat dengan cara melibatkan satu kelompok subjek. Kelompok subjek diobservasi sebelum dilakukan intervensi, kemudian di observasi lagi setelah dilakukan intervensi ${ }^{7}$.

Teknik sampling dalam penelitian ini adalah simple random sampling yaitu suatu tipe sampling probabilitas, dimana peneliti dalam memilih sampel dengan memberikan kesempatan yang sama kepada semua anggota populasi untuk ditetapkan sebagai anggota sampel.

Tabel 1. Desain Penelitian

\begin{tabular}{cccc}
\hline Subjek & Pra & Perlakuan & Pasca-tes \\
\hline K & O & I & Ol \\
& Waktu 1 & Waktu 2 & Waktu 3 \\
\hline
\end{tabular}

Sampel dalam penelitian ini didapatkan yaitu sebanyak 47 responden yaitu siswa SMA Katolik St. Petrus 
Pengaruh Pendidikan Kesehatan Terhadap Tingkat Pengetahuan Remaja Dalam Pencegahan Penyalahgunaan Nafza Di SMA Katolik St. Petrus Kanisius Palangka Raya

Kanisius Palangka Raya. Pengumpulan data penelitian ini dilakukan dengan menggunakan instrumen berupa kuisioner yang digunakan untuk mengukur tingkat pengetahuan dalam bentuk 30 pertanyaan tertutup dengan pilihan jawaban ganda (multiple choice).

Analisis data yang dilakukan pada hasil penelitian ini adalah analisis univariat dan bivariate. Hasil analisis univariat disajikan secara matematis dalam bentuk tabel yang gambar hasil identifikasi tingkat pengetahuan sebelum pendidikan kesehatan dan tingkat pengetahuan setelah pendidikan kesehatan. Sedangkan distribusi frekuensi responden meliputi: umur, jenis kelamin, pernah atau tidak mendapatkan informasi, dan sumber informasi. Analisis bivariat dilakukan untuk melihat perbedaan masing-masing variabel dependen dan independen, perbedaan dianggap bermakna bila nilai $p$ adalah $<$ level of significance $(<5 \%=0,05)$. Analisis dataada 2 untuk uji beda berpasangan (Uji Wilcoxon).

Prinsip etika penelitian tetap dilakukan untuk melindungi subjek penelitian.

\section{HASIL PENELITIAN}

\section{Variabel Tingkat Pengetahuan (Pre- test)}

Berikut ini merupakan hasil identifikasi tingkat pengetahuan sebelum diberikan pendidikan kesehatan pada siswa di SMA Katolik St. Petrus Kanisius Palangka Raya.
Tabel 2 Hasil identifikasi Tingkat Pengetahuan sebelum diberikan Pendidikan Kesehatan.

\begin{tabular}{llcc}
\hline \multicolumn{1}{c}{ Variabel } & Kategori & Jumlah & $\%$ \\
\hline Pengetahuan & Kurang & 30 & 64 \\
sebelum & Cukup & 16 & 34 \\
pendkes & Baik & 1 & 2 \\
\multicolumn{2}{c}{ Total } & 47 & 100 \\
\hline
\end{tabular}

Berdasarkan tabel diatas, dapat diketahui gambaran pengetahuan sebelum diberikan pendidikan kesehatan. Hasil dominan yang didapatkan yaitu responden sebanyak 30 orang $(64 \%)$ yang pengetahuannya termasuk dalam kategori "Kurang".

\section{Variabel Tingkat Pengetahuan (Post- Test)}

Berikut ini merupakan hasil identifikasi tingkat pengetahuan setelah diberikan pendidikan kesehatan pada siswa di SMA Katolik St. Petrus Kanisius Palangka Raya.

Tabel 2 Hasil identifikasi Tingkat Pengetahuan setelah diberikan Pendidikan Kesehatan.

\begin{tabular}{llcc}
\hline \multicolumn{1}{c}{ Variabel } & Kategori & Jumlah & $\%$ \\
\hline Pengetahuan & Kurang & 5 & 10 \\
sesudah & Cukup & 15 & 33 \\
pendkes & Baik & 27 & 57 \\
\multicolumn{2}{c}{ Total } & 47 & 100 \\
\hline
\end{tabular}

Berdasarkan data pada tabel 2, dapat diketahui gambaran pengetahuan setelah diberikan pendidikan kesehatan yaitu dominan sebanyak 27 orang (53\%) adalah responden yang memiliki pengetahuan dalam kategori "Baik", 15 
(33\%) orang memiliki pengetahuan

"Cukup" dan masih ada responden yang memiliki pengetahuan yang "Kurang" sebanyak 5 orang (10\%).

\section{Analisis Pengaruh Pendidikan Kesehatan Terhadap Peningkatan Tingkat Pengetahuan}

Berikut ini merupakan hasil analisis pengaruh pendidikan kesehatan terhadap tingkat pengetahuan siswa di SMA Katolik St. Petrus Kanisius Palangka Raya.

Tabel 4. Analisis Pengaruh Pendidikan Kesehatan Terhadap Tingkat Pengetahuan

\begin{tabular}{lcccc}
\hline \multicolumn{1}{c}{ Variabel } & $\mathrm{N}$ & Mean & $\begin{array}{c}\text { Std. } \\
\text { Deviation }\end{array}$ & $\begin{array}{c}\text { Asymp. } \\
\text { Sig. (2- } \\
\text { tailed) }\end{array}$ \\
\hline $\begin{array}{l}\text { Tingkat } \\
\begin{array}{l}\text { Pengetahuan } \\
\text { (pre-test) }\end{array}\end{array}$ & 47 & 2,63 &, 615 & \\
$\begin{array}{l}\text { Tingkat } \\
\begin{array}{l}\text { Pengetahuan } \\
\text { (post-test) }\end{array}\end{array}$ & 47 & 1,73 &, 450 & 0,000 \\
\hline
\end{tabular}

Berdasarkan hasil analisis uji statistic dengan menggunakan uji wilcoxon diatas dengan nilai 0,000 didapatkan $P$ Value $<\alpha$ 0,05 yang artinya Ha diterima yaitu ada pengaruh pendidikan kesehatan terhadap tingkat pengetahuan remaja dalam pencegahan penyalahgunaan NAPZA di SMA Katolik St. Petrus Kanisius Palangka Raya.

\section{PEMBAHASAN}

Pengetahuan (Knowledge) merupakan hasil dari tahu yang terjadi setelah orang melakukan penginderaan terhadap objek tertentu. Sebagian besar pengetahuan diperoleh melalui mata dan telinga. Pengetahuan merupakan pedoman dalam membentuk tindakan seseorang

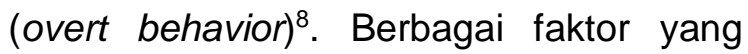
mempengaruhi pengetahuan seseorang yaitu umur adalah suatu variabel yang diperlukan dalam penyelidikan epidemiologi, yaitu pada angka kesakitan atau kematian, hampir semua keadaan menunjukkan pada keadaan umur seseorang ${ }^{9}$. Pendidikan adalah proses tumbuh kembang seluruh kemampuan dan perilaku manusia melalui pengajaran, sehingga dalam pengajaran itu perlu dipertimbangkan ilmu dan proses belajar, tingkat pendidikan juga merupakan salah satu faktor yang mempengaruhi persepsi seseorang untuk menerima ide-ide dan tekhnologi yang baru, semakin meningkat batas seseorang, maka akan bertambah pengalaman yang mempengaruhi wawasan dan pengetahuan. Informasi yang diperoleh baik dari pendidikan formal dan nonformal dapat memberikan pengaruh jangka pendek sehingga menghasilkan perubahan atau peningkatan pengetahuan. Pendidikan formal merupakan pendidikan yang diselenggarakan sekolah-sekolah pada umumnya jalur pendidikan itu memiliki jenjang pendidikan yang jelas, mulai dari pendidikan dasar, pendidikan menengah, sampai pendidikan tinggi.

Pernyataan tersebut sejalan dengan hasil penelitian pengaruh pendidikan kesehatan terhadap tingkat pengetahuan siswa tentang bahaya 
Pengaruh Pendidikan Kesehatan Terhadap Tingkat Pengetahuan Remaja Dalam Pencegahan Penyalahgunaan Nafza Di SMA Katolik St. Petrus Kanisius Palangka Raya

NAPZA di Madrasah Aliyah Mlftahul Jannah Kelurahan Pahandut Seberang Kota Palangka Raya ${ }^{10}$. Pengetahuan adalah hasil penginderaan manusia, atau hasil tahu seseorang terhadap objek melalui indera yang dimilikinya (mata, hidung, telinga, dan sebagainya). Pengetahuan yang diperoleh tergantung pada sejauh mana seseorang tersebut mampu memfokuskan perhatian dan persepsinya terhadap suatu objek berdasarkan penginderaan yang telah dilakukannya. Kemampuan seseorang dalam memperoleh pengetahuan juga dipengaruhi oleh beberapa hal seperti keadaan fisik, kognitif, tingkat perkembangan, serta dalam kemampuan intelektualnya.

Berdasarkan hasil penelitian, ada beberapa kesamaan antara fakta dan teori mengenai pengetahuan. Sebelum diberikan pendidikan kesehatan mengenai pencegahan penyalahgunaan NAPZA, seluruh responden yang berjumlah 47 orang memiliki pengetahuan yang kurang hal ini dikarenakan banyak yang belum pernah mendapatkan informasi tentang pencegahan penyalahgunaan NAPZA. Hasil dari penelitian ini banyak remaja yang belum pernah mendapatkan informasi tentang pencegahan penyalahgunaan NAPZA. Hal ini dipengaruhi oleh kurangnya minat serta keingintahuan siswa untuk mencari informasi yang menyebabkan ketidaktahuan tentang suatu hal yang belum diketahui individu tersebut. Oleh karena itu dengan adanya informasi baru mengenai sesuatu hal dapat memberikan landasan kognitif baru bagi terbentuknya pengetahuan terhadap informasi yang diperoleh baik dari pendidikan formal maupun non formal dan pengalaman bekerja yang dikembangkan akan memberikan suatu pengetahuan.

Pendidikan kesehatan adalah proses perubahan perilaku yang dinamis dimana perubahan tersebut bukan sekedar proses transfer materi/teori dari seseorang ke orang lain dan pula seperangkat prosedur, tetapi perubahan tersebut terjadi karena adanya kesadaran dari dalam diri individu, kelompok, atau masyarakat itu sendiri ${ }^{11}$. Pendidikan kesehatan adalah meningkatkan kemampuan masyarakat untuk memelihara dan meningkatkan derajat kesehatan; baik secara fisik, mental dan sosialnya, sehingga produktif secara ekonomi maupun social, pendidikan kesehatan disemua program kesehatan; baik pemberantasan penyakit menular, sanitasi lingkungan, gizi masyarakat, pelayanan kesehatan, maupun program kesehatan lainnya ${ }^{5}$. Pendidikan kesehatan adalah istilah yang diterapkan pada pengunaan proses pendidikan secara terencana untuk mencapai tujuan kesehatan yang meliputi beberapa kombinasi dan kesepakatan belajar atau aplikasi pendidikan didalam bidang kesehatan $^{12}$. 
Pendidikan kesehatan yang diberikan dengan baik dan benar maka akan membantu meningkatkan pengetahuan seseorang, kelompok, maupun masyarakat selain itu dengan pemberian pendidikan kesehatan sebagai informasi dapat membantu mempercepat seseorang untuk memperoleh pengetahuan yang baru. Setelah diberikan pendidikan kesehatan sebagian besar responden mengalami peningkatan pengetahuan, mereka tidak hanya telah mengetahui namun juga telah mampu memahami tentang pencegahan penyalahgunaan NAPZA dengan baik dan secara keseluruhannya seperti dampak bagi individu, lingkungan sosial, dan masyarakat.

Berdasarkan hasil penelitian didapatkan ada beberapa kesamaan antara fakta dan teori pengetahuan terhadap peningkatan pengetahuan siswa tentang pencegahan penyalahgunaan NAPZA, memberikan informasi melalui pendidikan kesehatan dengan melakukan penyuluhan tentang pencegahan penyalahgunaan NAPZA terjadi adanya perubahan pengetahuan pada siswa setelah diberikan pendidikan kesehatan mengalami peningkatan pengetahuan yang baik.

Pendidikan kesehatan diberikan untuk membantu individu, keluarga, dan masyarakat untuk mencapai tingkat kesehatan yang optimal. Pendidikan kesehatan bertujuan untuk mengubah perilaku individu, keluarga, dan masyarakat dari perilaku tidak sehat menjadi sehat. Perilaku yang tidak sesuai dengan nilai-nilai kesehatan, menjadi perilaku yang sesuai dengan nilai-nilai kesehatan atau perilaku negatif ke perilaku positif. Sesuai dengan teori yang menyatakan bahwa tingkat pengetahuan seseorang salah satunya dipengaruhi oleh adanya informasi yang diberikan atau diterima. Pendidikan kesehatan merupakan salah satu faktor yang mempengaruhi tingkat pengetahuan seseorang, dari yang tidak tahu menjadi tahu.

Pendidikan kesehatan adalah proses perubahan perilaku yang dinamis dimana perubahan tersebut bukan sekedar proses transfer materi/teori dari seseorang ke orang lain dan pula seperangkat prosedur, tetapi perubahan tersebut terjadi karena adanya kesadaran dari dalam diri individu, kelompok, atau masyarakat itu sendiri. Pendidikan kesehatan adalah meningkatkan kemampuan masyarakat untuk memelihara dan meningkatkan derajat kesehatan; baik secara fisik, mental dan sosialnya, sehingga produktif secara ekonomi maupun social, pendidikan kesehatan disemua program kesehatan; baik pemberantasan penyakit menular, sanitasi lingkungan, gizi masyarakat, pelayanan kesehatan, maupun program kesehatan lainnya. Pendidikan kesehatan adalah istilah yang diterapkan pada pengunaan proses pendidikan secara terencana untuk mencapai tujuan kesehatan yang meliputi beberapa kombinasi dan kesepakatan belajar atau 
Pengaruh Pendidikan Kesehatan Terhadap Tingkat Pengetahuan Remaja Dalam Pencegahan Penyalahgunaan Nafza Di SMA Katolik St. Petrus Kanisius Palangka Raya aplikasi pendidikan didalam bidang kesehatan ${ }^{13}$.

Pernyataan tersebut sejalan dengan penelitian pengaruh penyuluhan tentang NAPZA terhadap sikap dan pengetahuan remaja kelas XI di MAN Yogyakarta II. Remaja pada umumnya ingin memulai atau mencoba sesuatu yang belum pernah dia ketahui, remaja mempunyai rasa ingin tahu yang tinggi dan berusaha untuk mendapatkan informasi yang diinginkan ${ }^{14}$. Pemberian informasi yang akurat dan tepat sangat penting bagi remaja dalam membentuk sikap terhadap sesuatu yang dihadapi. Perubahan sikap dapat dipengaruhi oleh informasi yang didapat melalui pengetahuan, sikap, dan praktik. Hasil post-test menunjukkan dengan adanya intervensi yang diberikan melalui pendidikan kesehatan dapat memberikan perubahan sikap menjadi lebih baik atau kearah positif.

\section{KESIMPULAN}

Terdapat pengaruh pada tingkat pengetahuan setelah diberikan pendidikan kesehatan dibuktikan dari hasil analisis uji statistic Wilcoxon yaitu $p$-value $0,000 \leq 0,05$ yang artinya ada pengaruh pendidikan kesehatan terhadap tingkat pengetahuan Tentang pencegahan penyalahgunaan NAFZA pada remaja di SMA Katolik St. Petrus Kanisius Palangka Raya.

\section{SARAN}

Hasil penelitian ini dapat menjadi sumber informasi bagi petugas kesehatan

terutama perawat dalam memberikan asuhan keperawatan pada tatanan komunitas terkait pendidikan kesehatan terhadap tingkat pengetahuan remaja mengenai pencegahan penyalahgunaan NAPZA. Hasil penelitian ini dapat dijadikan sebagai sumber data bagi petugas kesehatan di Puskesmas untuk dilakukan tindak lanjut bagi anak sekolah dalam rangka meningkatkan derajat kesehatan yang optimal.

\section{DAFTAR PUSTAKA}

1. Asti, Yeli. 2014. Hubungan Pengetahuan Dan Sikap Terhadap Perilaku Penyalahgunaan Narkoba Pada Siswali SMP Negeri 4 Kecamatan Pontianak Timur Kotamadya Pontianak. Jurnal Universitas Tanjungpura Pontianak.

2. Sholihah, Qomariyatus. 2014. Efektivitas Program P4GN Terhadap Pencegahan Penyalahgunaan NAPZA. Jurnal Universitas Lambung Mangkurat.

3. UNODC. 2015. World Drug Report 2015. New York: United Nations.

4. BNN. 2014. Jurnal Data Pencegahan dan Pemberantasan Penyalahgunaan dan Peredaran Gelap Narkoba (P4GN) Tahun 2013. Diakses pada tanggal 14 Maret 2016 dari http://www.bnn.go.id.

5. BNNP Kalimantan Tengah. 2015. Laporan Rekapitulasi Data Pelaksanaan Rehabilitasi Bagi Pecandu dan Korban Penyalahgunaan Narkotika.

6. Willis, Sofyan S. 2014. Remaja Dan Masalahnya: Mengupas Berbagai Bentuk Kenakalan Remaja Narkoba, Free Sex Dan Pemecahannya. Bandung: Alfabeta

7. Nursalam. 2017. Metodologi Penelitian IImu Keperawatan Edisi 4. Jakarta: Salemba Medika.

8. Wawan, A dan Dewi, M. 2010. Teori dan Pengukuran Pengetahuan Sikap dan Perilaku Manusia. Yogyakarta: Nuha Medika. 
9. Notoadmojo, Soekidjo. 2010. Promosi Kesehatan Teori Dan Aplikasinya. Jakarta: Rineka Cipta.

10. Meilitha Carolina, Septian Mugi Rahayu dan Elin Ria Resti. 2016. Pengaruh Pendidikan Kesehatan Terhadap Tingkat Pengetahuan Siswa Tentang Bahaya NAPZAdi Mandrasah Aliyah Miftahul Jannah Kelurahan Pahandut Seberang Kota Palangka Raya. Jurnal STIKes Eka Harap Palangka Raya.

11. Mubarak, Wahid lqbal dan Nurul Chayatin, 2009. IImu Kesehatan Masyarakat Teori dan Aplikasi. Jakarta: Salemba Medika.

12. Mubarak, W., Chayanti, N., \& Roxikin, K. 2009. Promosi Kesehatan. Yogyakarta: Graha IImu.

13. Notoadmojo, Soekidjo. 2013. Promosi Kesehatan Global. Jakarta: Salemba Medika.

14. Ambar Sumirat. 2015. Pengaruh Penyuluhan Tentang NAPZA Terhadap Sikap dan Pengetahuan Remaja Kelas XI di MAN Yogyakarta II. Jurnal STIKes 'Aisyiyah Yogyakarta. 